\title{
La bibliothèque mentale de Marcel Proust, sous la direction de Guillaume PERRIER
}

\section{Ludovico Monaci}

\section{(2) OpenEdition}

\section{Journals}

\section{Édition électronique}

URL : http://journals.openedition.org/studifrancesi/15755

DOI : 10.4000/studifrancesi. 15755

ISSN : 2427-5856

\section{Éditeur}

Rosenberg \& Sellier

\section{Édition imprimée}

Date de publication : 1 décembre 2018

Pagination : $524-525$

ISSN : 0039-2944

\section{Référence électronique}

Ludovico Monaci, «La bibliothèque mentale de Marcel Proust, sous la direction de Guillaume PERRIER », Studi Francesi [En ligne], 186 (LXII | III) | 2018, mis en ligne le 01 janvier 2019, consulté le 06 janvier 2021. URL : http://journals.openedition.org/studifrancesi/15755 ; DOI : https://doi.org/10.4000/ studifrancesi. 75755

Ce document a été généré automatiquement le 6 janvier 2021.

\section{(c) (i)}

Studi Francesi è distribuita con Licenza Creative Commons Attribuzione - Non commerciale - Non opere derivate 4.0 Internazionale. 


\title{
La bibliothèque mentale de Marcel Proust, sous la direction de Guillaume PERRIER
}

\author{
Ludovico Monaci
}

\section{RÉFÉRENCE}

La bibliothèque mentale de Marcel Proust, sous la direction de Guillaume PERRIER, Paris, Classiques Garnier, 2017, «Revue d'études proustiennes» 5, 458 pp.

1 Le cinquième numéro de la «Revue d'études proustiennes» ouvre les portes de la "bibliothèque mentale" de Marcel Proust, afin de retracer des lieux et des stylèmes qui seraient censés être les «remémorations», dans la Recherche, d'un auteur ou d'un climat culturel particuliers.

Une symétrie structure le volume. Les interventions de la «Première Partie. Auteurs» (pp. 23-274), sans remettre en question l'importance de l'objet livre (la bibliothèque de l'écrivain gardait de nombreux ouvrages dédicacés), soulignent la tendance de Marcel Proust à mémoriser et à intérioriser la pensée et l'écriture de ceux qui l'ont précédé. De la malléabilité des Lettres de Mme de Sévigné (où le héros perçoit un «côté Dostoïevski»), à la centralité de Saint-Simon (qui personnifie la mémoire aristocratique de l'Ancien Régime), en passant par le souvenir de Goethe et de Chateaubriand (modèles respectivement pour l'organisation du récit et pour les rêveries), le cadre des influences littéraires est complété par la figure monumentale de Hugo et par le roman populaire de Dumas. Ce bagage mémoriel appelle en jeu jusqu'à l'historiographie (Michelet), la philosophie (Nietzsche et Bergson) et l'art (Ruskin).

En parallèle, la «Deuxième Partie. Thématique et lectures» (pp. 275-448) approfondit l'alliance alchimique qui lie l'écriture et la mémoire, les deux éléments structurels du récit. Les analyses stylistiques, thématiques, discursives et lexicales détaillent le réservoir des connaissances de Marcel Proust, et décryptent le rapport qu'une telle 
portion de texte entretient avec la source citée, rappelée ou remaniée. Enfin, on ne pouvait pas négliger le revers de la médaille, à savoir la consécration de Marcel Proust en tant que "bibliothèque mentale" du panorama artistique qui suivit, tant littéraire que cinématographique.

4 Face à l'impossibilité matérielle de repérer en un seul volume tous les échos qui se réverbèrent dans la Recherche, la publication nous fournit les clés théoriques pour poursuivre productivement en ce sens. 